\title{
PENGEMBANGAN ALAT SKRINING UNTUK HIPERTENSI
}

\author{
Heryudarini Harahap'; Yekti Widodo1; Sri Muljati', Agus Triwinarto'; dan Imam Effendi² \\ ${ }^{1}$ Puslitbang Gizi dan Makanan, Bogor \\ 2Divisi Ginjal Hipertensi, FK-UI
}

ABSTRACT

\section{THE DEVELOPMENT OF SCREENING TOOL FOR HYPERTENSION}

The increasing prevalence of hypertension is an important public health problem contributing to significant excess disease and mortality. The risk factors of high blood pressure were smoking, sex, age, consumption, activity, obesity, and heredity. Studies showed that subjects didn't aware about their blood pressure as well as subjects' knowledge about risk and symptom of hypertension was not good. Hypertension prevention can be done by giving screening tools to detect the blood pressure as well as giving information about risk and symptom of hypertension. The objective of the study was to develop screening tool to detect hypertension. A cross-sectional survey was conducted in Bogor, North Jakarta and Tangerang district. Blood pressure was collected using spyhgmanometer. The JNC 7 was used to classify of hypertension. Screening tool and leaflet was developed based on the result of Basic Health Research data set as well as literature study. The study had three activities that were focus group discussion, validity and reliability, as well as screening tool trial. Results: Validity test showed that over 17 questions only 6 questions were valid $(p<0,05, r=0,176)$. After re-construction of screening tool questions then validity test was done again. Over 15 questions, 12 was valid $(p<0,05, r=0,07)$. Eventhough 3 questions were not valid that questions were still included in that screening tools. Reliabilty of screening tool was realiable ( $\alpha$ Cronbach's $=0.586$ ). The sensitivity $(S e)$ and Specificity $(\mathrm{Sp})$ of subjects that had been have 7 scores or higher was had Se 61.6 and $64.1 \mathrm{Sp}$ respectively. Conclusion: This study implies that hypertension screening tool can be used as screening tool to detect hypertension.

Keywords: hypertension, obesity, sensitivity, screening tool, specificity

\section{PENDAHULUAN}

Kejadian hipertensi secara global cenderung meningkat, terutama dinegara maju dan negara sedang mengalami transisi epidemiologi. Menurut The Joint National Committee (JNC 7) on Prevention, Detection, Evaluation, and Treatment of High Blood Pressure ${ }^{1}$ hipertensi dapat dikelompokkan dalam: prahipertensi apabila tekanan darah 120-139/80-89 mmHg; hipertensi I adalah 140-159/90-99 mmHg dan hipertensi II adalah $>160 />100 \mathrm{mmHg}$. Di Indonesia prevalensi hipertensi pada tahun 2002 dikalangan usia dewasa laki-laki dan perempuan masing-masing sebesar 27 persen dan 29 persen². Hasil Riset Kesehatan Dasar pada tahun 2007 menunjukkan hasil prevalensi hipertensi di Indonesia yaitu 31,3 persen pada laki-laki dan 31,9 persen pada perempuan ${ }^{3}$.

Beberapa faktor yang dapat meningkatkan risiko timbulnya hipertensi adalah keturunan, lingkungan, kegemukan, peningkatan asupan natrium, merokok, alkohol, dan lain-lain ${ }^{4}$. Berbagai hasil penelitian menunjukkan pengetahuan subjek tentang hipertensi bervariasi. Penelitian yang dilakukan di Australia pada pasien hipertensi menunjukkan 55 persen dapat menyebutkan gejala hipertensi, dimana 55 persen percaya bahwa stress dapat menyebabkan hipertensi ${ }^{5}$. Penelitian di Sudan menunjukkan dua pertiga dari subjek mempunyai skor pengetahuan yang tinggi tentang etiologi dan komplikasi dari hipertensi. Setengah dari subjek mengetahui cara menangani hipertensi, namun subjek mempunyai skor pengetahuan yang rendah tentang gejala hipertensi ${ }^{6}$. Hasil penelitian di Swedia menunjukkan pengetahuan tentang tekanan darah tinggi terutama tidak berasal dari fasilitas kesehatan, namun dari mass media ${ }^{7}$.

Hipertensi berhubungan dengan terjadinya penyakit jantung dan stroke ${ }^{8}$. Dalam kaitannya dengan upaya preventif hipertensi, faktor risiko yang dapat diubah tersebut perlu dikelola dengan baik, salah satunya melalui perubahan gaya hidup, aktivitas fisik, konsumsi dan aktivitas sehat lainnya. Upaya preventif dapat dilakukan diantaranya adalah dengan menggunakan suatu alat untuk skrining hipertensi untuk mendeteksi ada atau tidaknya 
hipertensi pada seseorang tanpa mengukur tekanan darah, selain itu alat skrining ini dapat memberikan informasi tentang faktor risiko dan gejala dari hipertensi.

Tujuan penelitian untuk mengembangkan alat skrining guna mendeteksi hipertensi. Adapun secara khusus penelitian ini bertujuan untuk 1) mengetahui validitas dan realibilitas alat skrining, 2) mengetahui sensitivitas dan spesifisitas alat skrining.

\section{METODE PENELITIAN}

Desain penelitian ini adalah crosssectional. Penelitian dilaksanakan di tiga kabupaten/kota di Provinsi Banten, DKI Jakarta dan Jawa Barat. Di Provinsi Banten dipilih Kabupaten Tangerang, DKI Jakarta dipilih Kota Jakarta Utara, dan Jawa Barat dipilih Kota Bogor. Penelitian dilaksanakan bulan Oktober Desember 2009.

Populasi penelitian adalah semua penduduk berusia 20 tahun ke atas dari ketiga Provinsi terpilih. Subjek adalah penduduk terpilih berusia 20 tahun ke atas yang berada di wilayah Kabupaten Tangerang, Kota Jakarta Utara, dan Kota Bogor. Subyek dengan karakteristik sosial ekonomi rendah adalah pengunjung Posyandu, dan Puskesmas sedangkan subyek dengan sosial ekonomi tinggi adalah pegawai, dengan kriteria golongan III ke atas. Perhitungan besar subjek untuk differences between correlation coefficient dengan effect size 0,30 (medium) power $80 \%$ dan $a=0,05$ (2-tailed) diperlukan sebanyak 180 orang per kelompok sosial ekonomi? .

Variabel penelitian adalah karakteristik sosial ekonomi dilakukan dengan menggunakan kuesioner terstruktur. Data tekanan darah dikumpulkan dengan sphygmomanometer. Pengukuran tekanan darah dilakukan sebanyak 3 kali dengan selang waktu 10 menit, kemudian dihitung rata-rata dari ketiga pengukuran. Sebelum dilakukan pengukuran subjek diistirahatkan sekitar 30 menit. Selama masa istirahat subjek diminta untuk tidak merokok, makan, dan beraktivitas fisik yang dapat mempengaruhi hasil pengukuran tekanan darah.

Pada Gambar 1 disajikan alur kerja penelitian. Alat skrining didasarkan pada faktorfaktor risiko dan gejala hipertensi. Focus group discussion (FGD) dilakukan untuk mempelajari apakah pesan yang disampaikan dalam alat skrining cukup komunikatif. FGD dilakukan menurut tingkat sosial ekonomi. Uji validasi dan reliabilitas dilakukan untuk menilai validitas dan reliabilitas alat skrining. Alat ukur untuk skrining dibandingkan dengan acuan hipertensi yaitu nilai tekanan darah $\geq 140 / 90 \mathrm{mmHg}$. Di samping itu juga untuk memperoleh umpan balik dan penilaian masyarakat tentang kualitas alat skrining yang meliputi sifat komunikatif, dekoratif dan aplikatif.

Hasil yang diperoleh yaitu formulir skrining selanjutnya diuji coba. Subjek untuk uji coba adalah karyawan kantor dan pengunjung Puskesmas. Subjek yang berusia 20 tahun keatas diberikan formulir skrining. Subjek yang menerima alat skrining 1) Subjek ini diberikan penjelasan sebelum penelitian (PSP) yang meliputi tujuan, pelaksanaan, manfaat, waktu yang dibutuhkan, dan hak untuk mengundurkan diri. 2) Diminta kesediaannya untuk mengisi formulir sosial ekonomi yang berisi identitas, pendidikan, pendapatan, dan lain-lain, serta 3) Mengisi alat skrining. 


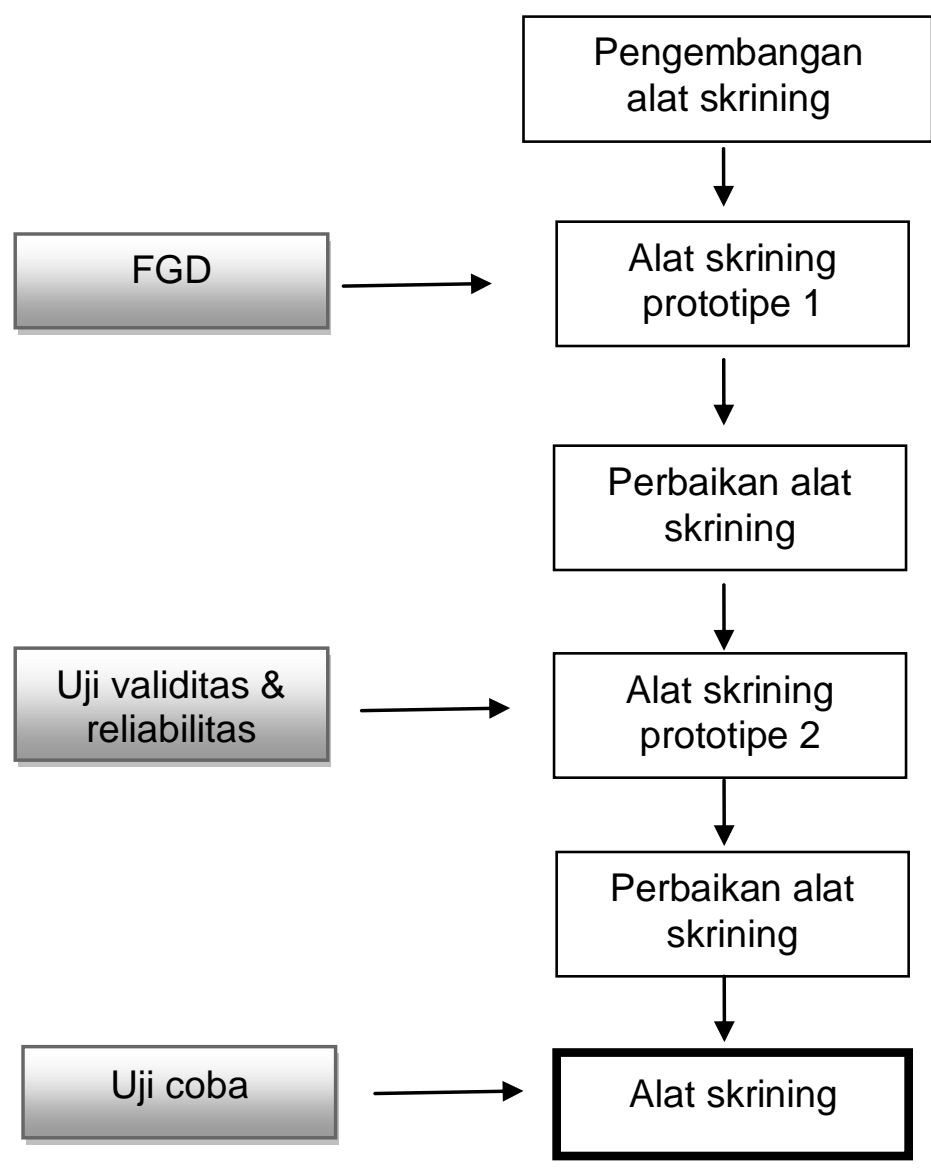

Gambar 1

Alur kerja penelitian

Uji statistik untuk mengetahui keragaman data sosial ekonomi digunakan uji Chi-square dan uji $t$. Uji Chi-square digunakan untuk menguji kesamaan distribusi peubah nonparametrik yaitu jenis kelamin dan status perkawinan, sedangkan uji $t$ digunakan untuk membandingkan perbedaan peubah parametrik yaitu umur.

Uji validitas dan reliabilitas dilakukan untuk menguji validitas dan reliabilitas dari alat skrining hipertensi. Analisis sensitivitas dan spesifisitas dilakukan untuk membandingkan hasil skor alat skrining hipertensi dibandingkan dengan pengukuran tekanan darah menggunakan sphygmanometer.

\section{HASIL}

Daftar pertanyaan dan pernyataan pada formulir skrining dikembangkan dan disusun berdasarkan telaah pustaka dari berbagai hasil penelitian dan analisis data Riskesdas 2007. Hasil analisis Riskesdas ditemukan faktor-faktor risiko hipertensi pada sosek rendah maupun tinggi adalah sama yaitu merokok, minum alkohol, jenis kelamin, dan umur. Berdasarkan hasil penelitian terdahulu faktor lain yang berhubungan erat dengan kejadian hipertensi adalah genetik, kegemukan, pola makan, stress, dan merokok, sehingga dalam menyusun alat skrining hipertensi selain memasukkan faktor umur, dan aktivitas juga mencakup faktor lain yang berhubungan erat dengan hipertensi.

Prototipe awal alat skrining dan leaflet hipertensi disajikan pada Gambar 2. Jumlah pertanyaan dari alat skrining hipertensi terdiri dari 16 pertanyaan. Pertanyaan alat skrining hipertensi terdiri dari pertanyaan tentang genetik, keadaan tubuh, usia, merokok, minum alkohol, jenis dan frekuensi olahraga, serta pola makan. 
FORMULIR SKRINING HIPERTENS

Nama

Tgl Lahir/umur

Alamat lengkap

Cara Pengisian:

- Beri tanda $V$ atau $X$ jawaban yang sesuai dengan keadaan anda

- Isi ..... sesuai dengan keadaan anda

\begin{tabular}{|c|c|c|c|}
\hline No. & Pertanyaan Skrining Hipertensi & Ya & Tidak \\
\hline \multirow[t]{4}{*}{1.} & Apakah ada keluarga anda menderita hipertensi & & \\
\hline & - Bapak/ibu kandung & & \\
\hline & - Saudara sekandung & & \\
\hline & - Kakek/nenek & & \\
\hline \multirow[t]{5}{*}{2.} & Keadaan tubuh anda sekarang & & \\
\hline & - $\quad$ Kurus & & \\
\hline & - Normal & & \\
\hline & - Gemuk & & \\
\hline & - Gemuk sekali & & \\
\hline \multirow[t]{4}{*}{3.} & Usia anda sekarang: & & \\
\hline & - $30-39$ tahun & & \\
\hline & $-\quad 40-49$ tahun & & \\
\hline & - 50 tahun lebih & & \\
\hline \multirow[t]{2}{*}{4.} & Apakah anda sekarang merokok & & \\
\hline & Kalau ya, berapa bungkus per hari & ....... & ....... \\
\hline 5. & Apakah anda sekarang minum alkohol & & \\
\hline \multirow[t]{4}{*}{6.} & Olah raga yang anda lakukan & & \\
\hline & - Ringan (misalnya jalan kaki, senam) & & \\
\hline & - Sedang (misalnya bersepeda di tempat datar, lari ditempat) & & \\
\hline & - $\quad$ Berat (misalnya lari mendaki, tenis, basket) & & \\
\hline \multirow[t]{5}{*}{7.} & Frekuensi olah raga & & \\
\hline & - Kurang dari 1 kali/minggu & & \\
\hline & - $1 \mathrm{kali} / \mathrm{minggu}$ & & \\
\hline & - $2-3 \mathrm{kali} / \mathrm{minggu}$ & & \\
\hline & - Lebih dari 4 kali/minggu & & \\
\hline \multirow[t]{2}{*}{8.} & Apakah anda setiap hari makan sayur & & \\
\hline & Jika ya, berapa mangkok per hari & $\ldots . .$. & ..... \\
\hline \multirow[t]{3}{*}{9.} & Apakah anda biasa makan buah & & \\
\hline & Jika ya, berapa kali per minggu & $\ldots .$. & ...... \\
\hline & Berapa kali per hari & $\ldots . .$. & ..... \\
\hline 10. & Apakah anda selama ini senang dengan makanan yang asin & & \\
\hline 11. & Apakah anda selama ini senang dengan makanan yang berlemak & & \\
\hline 12. & Apakah anda sering merasa sakit kepala & & \\
\hline 13. & Apakah anda sering merasa sakit/kaku di tengkuk & & \\
\hline 14. & Apakah anda sedang merasa tertekan di lingkungan kerja & & \\
\hline 15. & Apakah anda sedang merasa tertekan di lingkungan keluarga/rumah & & \\
\hline 16. & Apakah anda sering sulit tidur & & \\
\hline
\end{tabular}

Gambar 2

Alat skrining hipertensi pada FGD (prototipe 1) 


\section{Focus Group Discussion (FGD)}

Alat skrining yang telah dikembangkan kemudian didiskusikan dengan cara FGD dengan informan kader Posyandu, tokoh masyarakat (kepala desa, ketua RW dan ketua $\mathrm{RT}$ ), dan pegawai negeri sipil non kesehatan. Jumlah dan kelompok FGD yang dilakukan pada penelitian ini adalah 11 kelompok yang terdiri dari 5 kelompok dari sosek tinggi dan 6 kelompok dari sosek rendah.

FGD bertujuan untuk memperoleh umpan balik dari para informan tentang kemudahan penggunaan alat skrining. Kemudahan penggunaan alat skrining diperoleh dari penilaian para informan peserta FGD terhadap aspek 1) bahasa adalah mudah dimengerti dan sederhana (sifat komunikatif); 2) disain adalah warna, gambar, tata letak, dan ukuran huruf (sifat dekoratif); dan 3) isi adalah informasi yang disajikan dan manfaat (sifat aplikatif). Pada Tabel 1 tampak bahwa penilaian informan FGD terhadap alat skrining hipertensi lebih dominan pada aspek bahasa. Hal ini menunjukkan bahwa alat skrining tersebut dinilai masih kurang komunikatif, baik menurut kelompok sasaran sosek tinggi maupun sosek rendah. Dari aspek disain tanggapan yang dominan adalah pada ukuran huruf yang dinilai terlalu kecil sehingga agak sulit dibaca, sedangkan dari aspek isi informan menyatakan bahwa informasi tersebut sudah cukup baik.

Tabel 1

Hasil penilaian informan FGD terhadap alat skrining

\begin{tabular}{|c|c|c|}
\hline \multirow{2}{*}{ Aspek penilaian } & \multicolumn{2}{|c|}{ Alat skrining } \\
\hline & Sosek rendah & Sosek Tinggi \\
\hline Bahasa & $\begin{array}{l}\text { - Masih ada pertanyaan yang sulit } \\
\text { dipahami } \\
\text { - Pertanyaan kurang sederhana }\end{array}$ & $\begin{array}{l}\text { - Masih ada pertanyaan yang kurang } \\
\text { jelas } \\
\text { - Pertanyaan kurang sistematis }\end{array}$ \\
\hline Disain & - Huruf terlalu kecil & $\begin{array}{l}\text { - Huruf terlalu kecil } \\
\text { - Setiap pertanyaan perlu warna yang } \\
\text { berbeda }\end{array}$ \\
\hline Isi & - Cukup baik & $\begin{array}{l}\text { - Cukup baik } \\
\text { - Perlu petunjuk cara pengisian }\end{array}$ \\
\hline
\end{tabular}

\section{Uji validitas dan realibilitas alat skrining}

Berdasarkan hasil penilaian informan peserta FGD terhadap alat skrining pada kedua kelompok masyarakat, kemudian dilakukan perbaikan dan desain ulang terhadap prototipe 1 (Gambar 3). Pada uji validitas dan reliabilitas, pertanyaan/pernyataan terdiri dari 17 pertanyaan/pernyataan. Jenis pertanyaan/ pernyataan sama dengan ketika dilakukan FGD, namun dilakukan perubahan dalam pertanyaan tentang olah raga. Pada uji validitas dan reliabilitas, pertanyaan tentang olah raga di rinci menjadi olah raga ringan, sedang dan berat.

Alat skrining hasil perbaikan (prototipe kedua) kemudian divalidasi untuk menilai risiko seseorang terhadap hipertensi. Jumlah sampel yang digunakan untuk melakukan validasi adalah 134 orang yang terdiri dari pengunjung Puskesmas yang datang berobat atau mengantarkan keluarga berobat ke Puskesmas dan para pegawai di lingkungan kantor pemerintah daerah wilayah penelitian. 
FORMULIR SKRINING KESEHATAN

Nama Jenis kelamin: TgI Lahir/umur

Cara Pengisian:

- Lingkari jawaban yang sesuai dengan keadaan anda :

- Isi ..... sesuai dengan keadaan anda

\begin{tabular}{|c|c|c|c|}
\hline No. & Pertanyaan Skrining Hipertensi & & \\
\hline \multirow[t]{4}{*}{1.} & Apakah keluarga anda ada yang menderita hipertensi & & \\
\hline & - Bapak/ibu kandung & Ya & Tidak \\
\hline & - Saudara sekandung & Ya & Tidak \\
\hline & - Kakek/nenek & Ya & Tidak \\
\hline \multirow[t]{5}{*}{2.} & Keadaan tubuh anda sekarang & & \\
\hline & - Kurus & Ya & Tidak \\
\hline & - Normal & Ya & Tidak \\
\hline & - Gemuk & Ya & Tidak \\
\hline & - Gemuk sekali & $\mathrm{Ya}$ & Tidak \\
\hline \multirow[t]{4}{*}{3.} & Berapa usia anda sekarang: & & \\
\hline & - $30-39$ tahun & Ya & Tidak \\
\hline & $-40-49$ tahun & Ya & Tidak \\
\hline & - 50 tahun lebih & Ya & Tidak \\
\hline \multirow[t]{2}{*}{4.} & Apakah anda selama ini merokok & Ya & Tidak \\
\hline & Kalau ya, berapa bungkus per hari & $\ldots \ldots$ & \\
\hline 5. & Apakah anda selama ini minum alkohol & Ya & Tidak \\
\hline \multirow[t]{5}{*}{6.} & Apakah anda melakukan olah raga ringan (misalnya jalan kaki, senam) & & \\
\hline & - Kurang dari 1 kali/minggu & Ya & Tidak \\
\hline & - $1 \mathrm{kali} / \mathrm{minggu}$ & Ya & Tidak \\
\hline & - $2-3 \mathrm{kali} / \mathrm{minggu}$ & Ya & Tidak \\
\hline & - Lebih dari $4 \mathrm{kali} / \mathrm{minggu}$ & Ya & Tidak \\
\hline \multirow[t]{5}{*}{7.} & $\begin{array}{l}\text { Apakah anda melakukan olah raga sedang (misalnya lari di tempat, } \\
\text { bersepeda) }\end{array}$ & & \\
\hline & - Kurang dari 1 kali/minggu & $\mathrm{Ya}$ & Tidak \\
\hline & - 1 kali/minggu & Ya & Tidak \\
\hline & - $\quad 2-3 \mathrm{kali} / \mathrm{minggu}$ & $\mathrm{Ya}$ & Tidak \\
\hline & - Lebih dari 4 kali/minggu & Ya & Tidak \\
\hline \multirow[t]{5}{*}{8.} & $\begin{array}{l}\text { Apakah anda melakukan olah raga berat (misalnya lari mendaki, tenis, } \\
\text { basket) }\end{array}$ & & \\
\hline & - Kurang dari 1 kali/minggu & $\mathrm{Ya}$ & Tidak \\
\hline & - 1 kali/minggu & Ya & Tidak \\
\hline & - $\quad 2-3 \mathrm{kali} / \mathrm{minggu}$ & Ya & Tidak \\
\hline & - $\quad$ Lebih dari 4 kali/minggu & $\mathrm{Ya}$ & Tidak \\
\hline \multirow[t]{2}{*}{9.} & Apakah anda setiap hari makan sayur & Ya & Tidak \\
\hline & Jika ya, berapa mangkok per hari & $\ldots . .$. & \\
\hline \multirow[t]{3}{*}{10.} & Apakah anda biasa makan buah & Ya & Tidak \\
\hline & Jika ya, berapa kali per minggu & $\ldots .$. & \\
\hline & Berapa kali per hari & $\ldots .$. & \\
\hline 11. & Apakah anda selama ini biasa makan makanan yang asin & Ya & Tidak \\
\hline 12. & Apakah anda selama ini biasa makan makanan yang bersantan & Ya & Tidak \\
\hline 13. & Apakah anda selama ini biasa makan makanan yang berlemak & Ya & Tidak \\
\hline 14. & Apakah anda sering merasa sakit kepala & Ya & Tidak \\
\hline 15. & Apakah anda sering merasa sakit/kaku di tengkuk & Ya & Tidak \\
\hline 16. & Apakah anda sedang merasa tertekan di lingkungan kerja/keluarga & Ya & Tidak \\
\hline 17. & Apakah anda sering sulit tidur & Ya & Tidak \\
\hline
\end{tabular}

Gambar 3

Alat skrining hipertensi uji validasi (prototipe 2)

Jumlah subjek yang dapat dianalisis adalah 134 orang yang terdiri dari 82 orang $(61.2 \%)$ subjek dari sosial ekonomi rendah dan 52 orang (38.8\%) dari sosial ekonomi tinggi. Pada Tabel
2 disajikan karakteristik subjek menurut tingkat sosial ekonomi. Proporsi subjek perempuan lebih besar dibandingkan dengan subjek lakilaki baik pada sosek rendah maupun tinggi. 
Tabel 2

Karakteristik subjek validasi menurut tingkat sosial ekonomi

\begin{tabular}{|c|c|c|c|c|c|}
\hline \multirow{2}{*}{ Karakteristik Subjek } & \multicolumn{4}{|c|}{ Tingkat Sosial Ekonomi } & \multirow{2}{*}{$p$} \\
\hline & \multicolumn{2}{|c|}{ Rendah } & \multicolumn{2}{|c|}{ Tinggi } & \\
\hline - Laki-laki & 29 & $(35.4)$ & 24 & $(46.2)$ & \\
\hline - Perempuan & 53 & $(64.6)$ & 28 & $(53.8)$ & \\
\hline Status perkawinan, $\mathrm{n}(\%)$ & & & & & 0.030 \\
\hline - Menikah & 64 & $(78.0)$ & 49 & $(94.2)$ & \\
\hline - Janda/duda & 12 & $(14.6)$ & 3 & $(5.8)$ & \\
\hline - Tidak menikah & 6 & (7.3) & 0 & $(0.0)$ & \\
\hline Umur, rata-rata, SD, tahun & \multicolumn{2}{|c|}{$44.8 \pm 11.2$} & \multicolumn{2}{|c|}{$45.1 \pm 7.6$} & 0.869 \\
\hline
\end{tabular}

Rata-rata umur subjek dari sosek rendah lebih muda dibandingkan dengan sosek tinggi, namun tidak terdapat perbedaan yang bermakna $(p>0.05)$ dari umur antara sosek rendah dan sosek tinggi.

Pertanyaan/pernyataan tentang hipertensi terdiri dari 17 pertanyaan. Uji validitas alat ukur yang dipergunakan menunjukkan dari 17 pertanyaan hanya 6 pertanyaan yang valid dengan batas kemaknaan $5 \%$, dengan nilai $r=$ 0.176. Perbaikan dilakukan terhadap alat skrining hipertensi, kemudian dilakukan uji validitas kembali. Dari 15 pertanyaan hipertensi 12 pertanyaan yang valid dengan batas kemaknaan $5 \%$, dengan nilai $r=0.07$. Meskipun ada 3 pertanyaan yang tidak valid dari alat skrining, namun pertanyaan tersebut tetap disertakan dalam alat skrining karena berdasarkan hasil penelitian ketiga faktor tersebut berpengaruh terhadap kejadian kegemukan atau hipertensi. Setelah dilakukan uji reliabilitas, alat skrining kegemukan dan hipertensi cukup reliabel yang ditunjukkan dengan nilai a Cronbach's adalah 0.586 .

Data sensitifitas (Se) dan spesifisitas (Sp) hasil uji validasi alat skrining hipertensi disajikan pada Tabel 3. Jumlah skor 7 keatas menunjukkan perbandingan nilai antara Se dan Sp yang terbaik. Penapisan dengan menggunakan alat skrining hipertensi menunjukkan bahwa sebanyak 52 persen subyek memiliki skor tujuh atau lebih besar dalam hal ini termasuk katagori hipertensi. Sedangan 67 persen termasuk tidak hipertensi atau memiliki skor kurang dari tujuh. Hasil validasi menunjukkan bahwa alat skrining hipertensi memiliki kemampuan sekitar 55 persen dalam mendeteksi kejadian hipertensi pada subjek.

Tabel 3

Nilai Sensitivitas (Se) dan Spesivisitas (Sp) Alat Skrining Hipertensi pada Validasi

\begin{tabular}{ccc}
\hline \multirow{2}{*}{ Jumlah Skor } & \multicolumn{2}{c}{ Hipertensi } \\
\cline { 2 - 3 } & Sensitivitas & Spesifisitas \\
\hline 4 & 88.0 & 20.2 \\
\hline 5 & 80.0 & 36.7 \\
\hline 6 & 72.0 & 49.5 \\
\hline 7 & 52.0 & 67.0 \\
\hline 8 & 16.0 & 76.1 \\
\hline 9 & 0.0 & 86.2 \\
\hline
\end{tabular}




\section{Uji coba alat skrining}

Berdasarkan hasil penilaian sampel uji validasi terhadap alat skrining dan leaflet pada kedua kelompok masyarakat, kemudian dilakukan perbaikan dan desain ulang terhadap prototipe 2. Hasil perbaikan dan disain ulang alat skrining dan leaflet prototipe 2 menjadi prototipe 3 dapat dilihat pada Gambar 4 .
Alat skrining prototipe 3 kemudian diuji coba untuk menilai risiko seseorang terhadap hipertensi. Subjek terdiri dari pengunjung Puskesmas yang datang berobat atau mengantarkan keluarga berobat ke Puskesmas dan para PNS di lingkungan pemerintah daerah wilayah penelitian. Tujuan utama uji coba adalah untuk mengetahui sensitivitas dan spesifisitas alat skrining hipertensi.

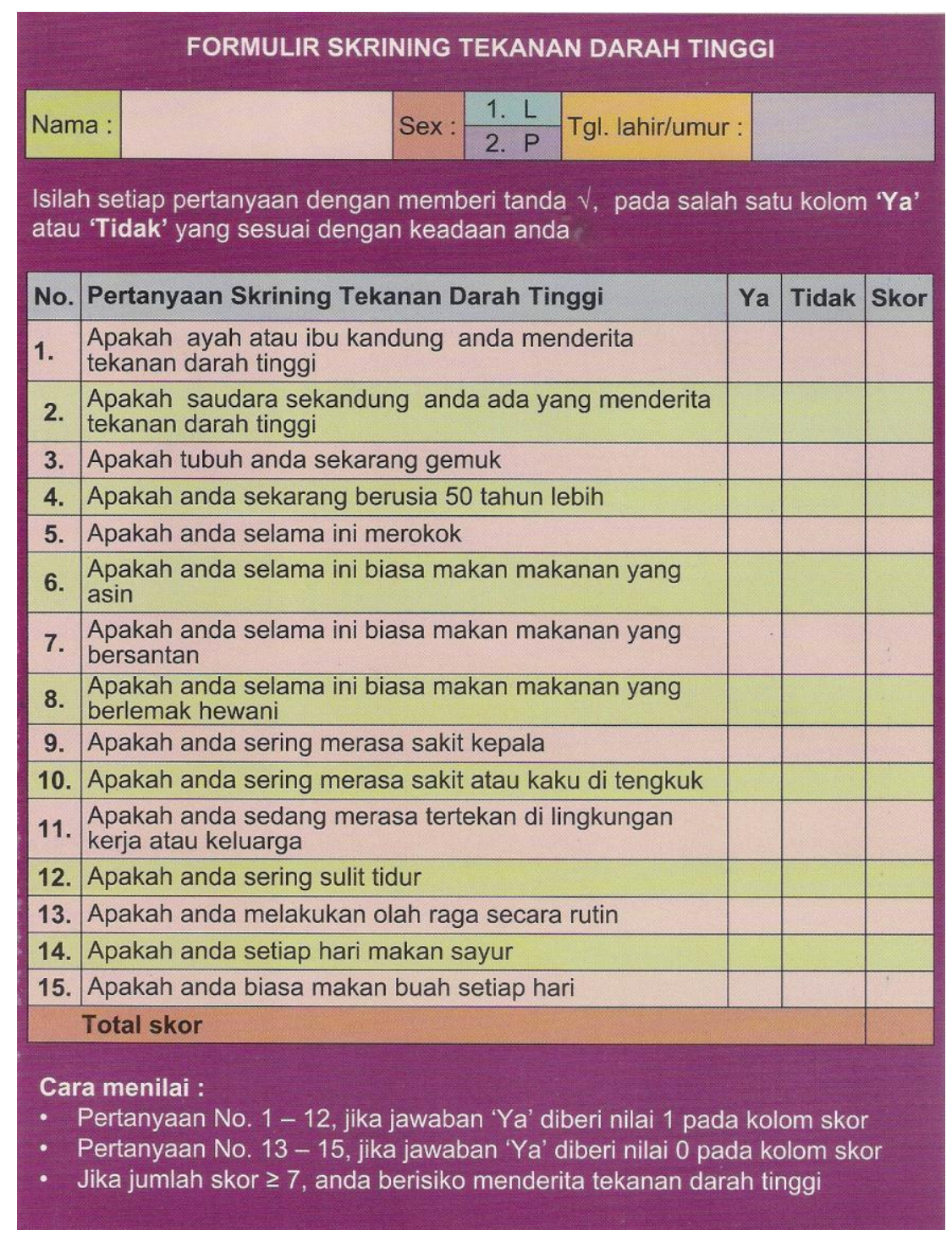

Gambar 4

Alat Skrining Hipertensi Uji Coba

Jumlah subjek yang dapat dianalisis adalah 685 orang yang terdiri dari 334 orang $(48.8 \%)$ subjek dari sosial ekonomi rendah dan 351 orang $(51.2 \%)$ dari sosial ekonomi tinggi. Pada Tabel 4 disajikan karakteristik subjek menurut tingkat sosial ekonomi. Proporsi subjek perempuan lebih besar dibandingkan dengan subjek laki-laki baik pada sosek rendah maupun tinggi. 
Tabel 4

Karakteristik subjek uji coba menurut tingkat sosial ekonomi

\begin{tabular}{|c|c|c|c|c|c|}
\hline \multirow{2}{*}{ Karakteristik Subjek } & \multicolumn{4}{|c|}{ Tingkat Sosial Ekonomi } & \multirow{2}{*}{$p$} \\
\hline & \multicolumn{2}{|c|}{ Rendah } & \multicolumn{2}{|c|}{ Tinggi } & \\
\hline - Laki-laki & 133 & $(39.8)$ & 142 & $(40.5)$ & \\
\hline - Perempuan & 201 & $(60.2)$ & 209 & $(59.5)$ & \\
\hline Status perkawinan, $\mathrm{n}(\%)$ & & & & & 0.000 \\
\hline - Menikah & 258 & $(77.2)$ & 325 & $(92.6)$ & \\
\hline - Janda/duda & 29 & (8.7) & 18 & (5.1) & \\
\hline - Tidak menikah & 47 & (14.1) & 8 & (2.3) & \\
\hline Umur, rata-rata, SD, tahun & \multicolumn{2}{|c|}{$38.9 \pm 11.3$} & \multicolumn{2}{|c|}{$44.2 \pm 8.2$} & 0.000 \\
\hline
\end{tabular}

Data sensitivitas (Se) dan spesifisitas (Sp) hasil uji ujicoba alat skrining hipertensi disajikan pada Tabel 5. Baik pada alat skrining hipertensi, jumlah skor 7 ke atas menunjukkan perbandingan nilai antara Se dan Sp yang terbaik. Penapisan dengan menggunakan alat skrining hipertensi menunjukkan bahwa sebanyak 61,6 persen subyek memiliki skor tujuh atau lebih besar dalam hal ini termasuk katagori hipertensi. Sedangan 64,1 persen termasuk tidak hipertensi atau memiliki skor kurang dari tujuh. Terjadi peningkatan nilai Se dan Sp pada uji coba, alat skrining memiliki kemampuan 60 persen dalam mendeteksi hipertensi.

Tabel 5

Nilai Sensitivitas (Se) dan Spesifisitas (Sp) alat skrining hipertensi pada uji coba

\begin{tabular}{ccc}
\hline \multirow{2}{*}{ Jumlah Skor } & \multicolumn{2}{c}{ Hipertensi } \\
\cline { 2 - 3 } & Sensitivitas & Spesifisitas \\
\hline 4 & 89.6 & 17.1 \\
\hline 5 & 83.2 & 33.2 \\
\hline 6 & 75.2 & 46.3 \\
\hline 7 & 61.6 & 64.1 \\
\hline 8 & 31.2 & 76.1 \\
\hline 9 & 19.2 & 87.2 \\
\hline
\end{tabular}

\section{BAHASAN}

Penelitian dilakukan di tiga kota/kabupaten. Pemilihan kota/kabupaten dilakukan dengan mempertimbangkan prevalensi hipertensi di wilayah tersebut, dengan demikian penelitian ini tidak dirancang untuk mewakili wilayah secara luas dengan berbagai karakteristik sosial, demografis, lingkungan, dan budaya masyarakat yang berbeda.
Penelitian ini dilakukan dengan desain crossectional yang memiliki keterbatasan antara lain hanya memotret satu saat sehingga tidak dapat menentukan hubungan sebab akibat. Selain itu dalam penelitian ini kemungkinan terjadinya bias seleksi yang mungkin akan berpengaruh terhadap hasil penelitian.

Hasil analisis Riskesdas menunjukkan bahwa faktor-faktor yang berhubungan dengan hipertensi baik pada sosial ekonomi tinggi maupun rendah adalah sama, yaitu merokok, 
minum alkohol, jenis kelamin, dan umur sehingga alat skrining untuk sosial ekonomi tinggi maupun rendah dibuat sama. Berdasarkan hasil penelitian terdahulu selain faktor-faktor yang ditemukan dari analisis Riskesdas yang berhubungan erat dengan kejadian hipertensi adalah genetik, kegemukan, pola makan dan stress sehingga dalam menyusun alat skrining hipertensi dimasukkan faktor-faktor tersebut.

Merokok dapat mengakibatkan peningkatan tekanan darah. Merokok akan mengakibatkan vasokontriksi pembuluh darah perifer dan pembuluh darah ginjal sehingga terjadi peningkatan tekanan darah. Merokok akan menyebabkan pembuluh darah mengalami penyempitan yang akan mengakibatkan jantung memompa darah lebih kuat sehingga tekanan pada pembuluh darah meningkat ${ }^{10}$. Zat-zat yang terkandung dalam asam rokok seperti karbon monoksida (CO), nikotin, dan sebagainya dapat merusak pembuluh darah ${ }^{11}$. Hasil penelitian menunjukkan merokok sebatang setiap hari akan meningkatkan tekanan sistolik $10-25 \mathrm{mmHg}^{12}$, penelitian lain menunjukkan ada hubungan rokok dengan hipertensi $(\mathrm{OR}=4,125 ; \mathrm{Cl}: 1,387-12,270)^{13}$.

Pada Tabel 7 disajikan pengaruh BB, makanan dan pola makan terhadap tekanan darah. Kegemukan merupakan suatu keadaan yang bermakna dalam memicu terjadinya hipertensi pada diri seseorang. Selain itu konsumsi natrium, karbohidrat, lemak jenuh, dan kolesterol berhubungan secara langsung dengan tekanan darah. Semakin meningkat konsumsinya semakin meningkat tekanan darah. Konsumsi kalium, serat, pola makan vegetarian, dan pola makan DASH (Dietary Approach to Stop Hypertension) berhubungan terbalik dengan tekanan darah. Semakin meningkat konsumsinya, maka tekanan darah akan turun ${ }^{14}$

Tabel 7

Hubungan Berat Badan, Zat Gizi dan Pola Makan pada Tekanan Darah: Ringkasan dari Berbagai Hasil Penelitian ${ }^{14}$

\begin{tabular}{lll}
\hline Variabel & Hipotesis & Hasil Penelitian \\
\hline Berat badan & Langsung & ++ \\
Natrium (garam) & Langsung & ++ \\
Kalium & Terbalik & ++ \\
Lemak jenuh & Langsung & $+/-$ \\
Karbohidrat & Langsung & + \\
Serat & Terbalik & + \\
Kolesterol & Langsung & $+/-$ \\
Pola makan & & \\
Vegetarian & Terbalik & ++ \\
DASH & Terbalik & ++ \\
\hline
\end{tabular}

+/- menunjukkan hasil penelitian yang terbatas atau; + hasil penelitian yang meyakinkan dari penelitian observasi dan penelitian klinis, dan ++ hasil penelitian yang meyakinkan dari penelitian klinis

Penelitian yang dilakukan pada orangorang yang berusia 18-22 tahun menunjukkan bahwa indeks massa tubuh berlebih mempunyai hubungan terhadap lebih tingginya tekanan darah. Hasil penelitian ini menemukan setiap 1 unit peningkatan IMT akan meningkatkan SBP 0,91 pada laki-laki dan $0,72 \mathrm{mmHg}$ pada perempuan; dan DBP 0,75 pada laki-laki dan $0,50 \mathrm{mmHg}$ pada perempuan. Hasil Survei Kesehatan Rumah Tangga tahun 2004 menunjukkan orang gemuk berisiko 1,85 kali dan orang obese berisiko 2,52 kali dibandingkan orang normal tekanan darahnya menjadi bordeline $(130-159 / 85-99 \mathrm{mmHg})^{16}$.

Genetik berarti secara keturunan seseorang mempunyai potensi untuk menderita hipertensi jika orang tua menderita hipertensi. Hipertensi juga banyak dijumpai pada penderita kembar monozigot (satu telur), apabila salah satu menderita hipertensi. Hubungan antara stress dengan hipertensi, diduga melalui aktivasi saraf simpatis yaitu adalah saraf yang bekerja pada saat beraktivitas. Peningkatan aktivitas saraf simpatis dapat meningkatkan 
tekanan darah secara intermitten (tidak menentu). Apabila stress berkepanjangan, dapat mengakibatkan tekanan darah menetap tinggi. Hasil penelitian menunjukkan penderita hipertensi lebih banyak pada laki-laki. Hormonhormon wanita disebutkan sebagai salah satu faktor yang mempengaruhi tekanan darah perempuan sehingga lebih rendah dibandingkan tekanan darah laki-laki. Di samping itu kromosom $\mathrm{X}$ berperan pada tekanan darah ${ }^{17}$.

Alat skrining ini dirancang untuk masyarakat awam supaya dapat mendeteksi hipertensi tanpa mengukur tekanan darah dan memahami faktor risiko atau gejala hipertensi. Berbagai hasil penelitian menunjukkan pengetahuan subjek tentang hipertensi bervariasi. Penelitian yang dilakukan di Australia pada pasien hipertensi menunjukkan 55 persen dapat menyebutkan gejala hipertensi, di mana 55 persen percaya bahwa stress dapat menyebabkan hipertensi ${ }^{5}$. Penelitian di Sudan menunjukkan dua pertiga dari subjek mempunyai skor pengetahuan yang tinggi tentang etiologi dan komplikasi dari hipertensi. Setengah dari subjek mengetahui cara menangani hipertensi, namun subjek mempunyai skor pengetahuan yang rendah tentang gejala hipertensi6. Hasil penelitian di Swedia menunjukkan pengetahuan tentang tekanan darah tinggi terutama tidak berasal dari fasilitas kesehatan, namun dari mass media ${ }^{7}$.

Penelitian ini membandingkan alat skrining dengan gold standard yaitu rata-rata pengukuran tekanan darah dengan menggunakan sphygmomanbometer. Penyakitpenyakit dengan prevalensi yang tinggi diutamakan adalah nilai sensitivitasnya karena untuk menekan false negative. Nilai Se dan Sp yang ditemukan pada penelitian ini dipengaruhi oleh tingkat pengetahuan rensponden tentang faktor risiko atau gejala hipertensi masih rendah dan tidak mengetahui tentang tekanan darahnya. Hasil penelitian ini menunjukkan Sensitivitas (Se) dan Spesifisitas (Sp) alat skrining masing-masing adalah 61,6 dan 64,1. Nilai Se dan Sp 60 persen dapat dikatakan cukup senstitif untuk mendeteksi orang yang benar-benar menderita hipertensi, dan cukup spesifik untuk mendeteksi yang benar-benar tidak hipertensi.

Penelitian tentang "Evaluating the Quality of Self-Report of Hypertension and Diabetes" menunjukkan Se dan Sp masing-masing adalah
48,9 dan 96,3 persen. Hasil penelitian menunjukkan self report hanya bisa sebesar 48,9 persen yang menderita hipertensi dan 96,3 persen mendeteksi orang benar-benar tidak menderita hipertensi ${ }^{18}$. Jika dibandingkan penelitian ini dengan penelitian sebelumnya nilai Se yang ditemukan lebih tinggi, sedangkan Sp lebih rendah. Jadi dapat dikatakan hasil penelitian ini cukup sensitif dan spesifik.

\section{SIMPULAN DAN SARAN}

\section{Simpulan}

1. Diperoleh alat skrining hipertensi yang valid dengan nilai $r=0.07$, dan cukup reliabel dengan nilai a Cronbach's adalah 0.586 .

2. Diperoleh alat skrining hipertensi yang cukup sensitif dan spesifik, dengan nilai Se dan Sp masing-masing adalah 61.6 dan 64.1.

\section{Saran}

1. Perlu penelitian lebih lanjut untuk mengkaji strategi pemasaran dari alat skrining yang telah dikembangkan.

2. Alat skrining dan leaflet dapat disebarkan di Puskesmas/pelayanan kesehatan lainnya, kantor-kantor, atau di Mini Market. Alat skrining dan leaflet dapat ini dapat digunakan oleh masyarakat sosial ekonomi rendah maupun tinggi.

\section{UCAPAN TERIMA KASIH}

1. Direktorat Jenderal Pendidikan Tinggi Departemen Pendidikan Nasional, RI yang telah memberikan dana untuk penelitian.

2. Bapak dan ibu responden yang telah bersedia menjadi subjek dalam penelitian ini.

\section{RUJUKAN}

1. US Departement of Health and Human Services. Complete Report: The Seventh Report of the Joint National Committee on Prevention, Detection, Evaluation, and Treatment of High Blood Pressure. National Institute of Health, and National Heart, Lung and Blood Institute, 2004.

2. Badan Litbang Kesehatan. Survei Kesehatan Rumah Tangga. Jakarta: Depkes, 2002. 
3. Departemen Kesehatan. Laporan Hasil Riset Kesehatan Dasar Indonesia Tahun 2007. Jakarta: Depkes, 2008.

4. Tara E dan Soetrisno. Buku Pintar Terapi Hipertensi. Jakarta: Restu Agung dan Tara Media, 1998.

5. Taylor C, and Ward A. Patients' views of high blood pressure, its treatment and risks. Aust Fam Physician. 2003 32(4): p278-82.

6. Osman EM, Suleiman I, Elzubair AG. Patients knowledge of hypertension and its control in Eastern Sudan. East Afr Med J. 2007, 84(7): p324-8

7. Kjellgren KI, Svensson S, Ahlner J, Saljo R. Hypertensive patients' knowledge of high blood pressure. Scan J Prim Health Care. 1997, 15(4):p188-92.

8. Popkin B et al. The nutrition transition and prevention of diet-related chronic diseases in Asia and Pacific. Asian Development Bank Series;6. 2001.

9. Cohen J. Statistical Power Analysis for the Behavior Sciences Differences between Correlation Coefficients. Revised ed. New York: Academic Press, 1997. p. 109-143.

10. Wardoyo. Pencegahan Penyakit Jantung Koroner. Solo: Toko Buku Agency, 1996.
11. Suparto. Sehat Menjelang Usia Senja. Bandung: Remaja Rosdakarya Offset, s.a.

12. Sitepoe M. Usaha Mencegah Bahaya Merokok. Jakarta: Gramedia, 1997.

13. Suheni, Y. Hubungan Antara Kebiasaan Merokok dengan Kejadian Hipertensi pada Laki-laki Usia 40 Tahun Keatas di Badan Rumah Sakit Daerah Cepu. Semarang: Universitas Negeri Semarang, 2007.

14. Appel et al. Dietary aproach to prevent and treatment hypertension: scientific statement from the American Heart Association. Hypertension 2006, 47 :296-308.

15. Pinzon R. Indeks massa tubuh sebagai faktor risiko hipertensi pada usia muda. Cermin Dunia Kedokteran 1999,123:9-11.

16. Sihadi dan Sri Poedji Hastuti Djaiman. Besarnya Risiko Kegemukan Terhadap Tekanan Darah. Penelitian Gizi dan Makanan 2006; 29(2):78-84.

17. Friedrich CL. Geneticism of Essential Hypertension. Journal of the American Heart Association, 2004, 4 (6):1155-1159

18. Goldman N et al. Evaluating the Quality of Self-Reports of Hypertension and Diabetes. S.l: Office of Research Princeton University, s.a. 